\title{
Technological competitiveness of the EU member states in the era of the fourth industrial revolution ${ }^{1}$
}

\author{
Marzenna Anna Weresa ${ }^{2}$
}

\begin{abstract}
The aim of this paper is to investigate the implications of the fourth industrial revolution for technological competitiveness, its definition and measurement methods. An empirical part is aimed at identifying comparative advantages of the European Union in digital technologies. Recently new approaches have appeared to measure digital competitiveness, however they use a broad definition of competitiveness that encompasses not only technological factors but also the macroeconomic and institutional environment (IMD, 2017; WEF, 2018). There is still a limited number of studies focused on the technological dimension of competitiveness in digital technologies. This paper fills the gap by developing a conceptual framework based on patent indicators, i.e. Patent Share and Revealed Technological Advantage indices. It allows a consistent analysis of the comparative advantages of the EU member states in digital technologies to be conducted. The results confirm a huge diversity within the EU in terms of digital technologies, their global impact and comparative advantages.
\end{abstract}

Keywords: technological competitiveness, digitalization, European Union, revealed technological advantage.

JEL codes: O30, O31, O34.

\section{Introduction}

The issue of international competitiveness and its links with technological development and national innovative capacity has been the focus of conceptual research since the 1980s, however in the era of the fourth industrial revolution this topic is gaining greater importance. Artificial intelligence, robotics, the Internet of things, big data analytics, cloud computing, augmented reality are signs of this new technological era known as Industry 4.0 (Kagermann, Helbig, Hellinger, \& Wahlster, 2013; Weresa, 2019).

\footnotetext{
${ }^{1}$ Article received 15 July 2019, accepted 20 August 2019.

${ }^{2}$ World Economy Research Institute, Collegium of World Economy, SGH Warsaw School of Economics, al. Niepodległości 162, 02-554 Warszawa, Poland, marzenna.weresa@sgh.waw. pl. ORCID: https://orcid.org/0000-0003-3112-3460.
} 
The Industry 4.0, which is a manifestation the fourth industrial revolution, has become an increasingly important issue discussed and researched by academics, companies and policy makers. The term "Industry 4.0" was used for the first time by the German government in the context of the digitalization strategy of the German manufacturing sector (BMBF, 2013). However, despite the increasing interest in this new paradigm, its conceptual framework is still not fully developed from the theoretical and methodological point of view. In particular there are ongoing discussions as to how the innovation and competitiveness of countries is changing in the digital age (Schwab, 2016; Morrar, Arman, \& Mousa, 2017; WEF, 2018; OECD, 2019).

Companies are also not fully prepared for the digital transformation, some of them are not aware of the challenges they may face in implementing the Industry 4.0 achievements. Industry 4.0 may require a deep transformation of their technological profiles and business models which in the long run will have an impact on countries' innovation and technological performance. Digital technologies change innovation practices in all sectors, including traditional ones. They are regarded as general purpose technologies as they can bring long-term productivity gains shaping the economic and social landscape (Planes-Satorra \& Paunov, 2019).

Key conceptual and methodological questions related to competitiveness seen in the context of the fourth industrial revolution are about the notion of countries' technological competitiveness, its indicators and measurement methods, in particular in the field of digital technologies. From the empirical research perspective the technological competitiveness of countries in the field of digital technologies also suffers from insufficient comparable approaches that would allow the benchmarking of countries and mapping their achievements and progress in this respect.

Therefore the main objective of this paper is to investigate the implications of the fourth industrial revolution for technological competitiveness, its definition and measurement methods, in particular in the field of digital technologies. An empirical part of this paper is aimed at identifying the comparative advantages of the EU member states in digital technologies. The research questions that will be answered in this paper are the following:

- How technological competitiveness should be understood in the era of the fourth industrial revolution?

- How to measure technological competitiveness in the digital age?

- How does the EU compare to world leaders in terms of the competiveness of digital technologies?

- Which EU member states have comparative advantages in digital technologies?

The paper is organized as follows. In the next two sections by using a literature review, a conceptual framework of technological competitiveness in the field of digital technologies and its measurement (indicators and data sources) 
are discussed. Then the competitive position in the field of digital technologies of the EU as a whole as well as of the EU individual member states is analyzed. In the last section the research findings are summarized and the main research limitations are presented.

\section{Building a conceptual framework for the technological dimension of competitiveness in the digital age-a literature review}

The economic literature on the technological dimension of competitiveness puts a lot of emphasis on the interrelationship between innovation and competitiveness. According to Porter (2008) the long-term competitive position of a country is related to the creation of new ideas and their commercialization. The importance of innovation and technology for countries' competitiveness has been also acknowledged within a framework based on a neo-Schumpeterian approach (see i.e. Grossman \& Helpman, 1989; Narula \& Wakelin, 1998; Uchida \& Cook, 2005; Chiappini, 2014).

However nowadays in the era of the fourth industrial revolution the nature of innovation has been changing. According to the OECD (2019, pp. 26-35) in a digital age the characteristics of innovation evolve in four directions: 1) innovation is increasingly based on data; 2) the focus of innovation processes is moving towards services which become more and more complementary to manufacturing; 3 ) the innovation cycles are faster than in the past with a growing need for experimentation and personalization; and 4) innovation processes require diverse forms of collaboration such as data sharing, partnerships, crowdsourcing, etc.

The digital transformation can change innovation processes significantly by reducing the costs of production and the dissemination of knowledge, goods and services. Digitized knowledge can be shared at the same time by many users. This may cause improvements and an acceleration of R\&D and innovation processes and reduce the costs of production and commercialization of new products (OECD, 2019, p. 26). Smart and connected products differ from traditional products in many ways. They have larger intangible components which can be simultaneously used in multiple locations. Intangible assets can be divided into three broad categories: information (i.e. databases and software), intangible innovative property (i.e. $\mathrm{R} \& \mathrm{D}$, copyright and license, design) and investment in competences and skills (i.e. investment in firm-specific human capital, changes in organizational structure, market research) (van Ark, Hao, Corrado, \& Hulten, 2009, p. 90). As Haskel and Westlake (2017, p. 58) point out there are four important features of intangible investment: scalability, sunkenness, spillovers and synergies. Scalability refers to the large scale of intangi- 
ble-intensive businesses, which is enhanced by network effects. Some costs of the creation of intangible assets are irrecoverable and if the knowledge is not protected by formal intellectual property rights (such as patents) it is difficult (or sometimes impossible) to sell it, which explains its "sunkenness" feature. The results of investment in knowledge can be relatively easily used by others, therefore they have high spillover effects. These spillovers can arise from R\&D but they also can occur in marketing or organizational activity. The fourth feature of intangible investment-synergies-is perfectly described by Haskel and Westlake (2017, p. 79): "Ideas with other ideas go well together. This is especially true in the field of technology". These synergies of intangible investment also occur with human capital.

The four features of intangible investment described above can have an impact on the costs of development, production and commercialization of new products, intellectual property protection, networking and collaboration, market structure, etc. As a result the productivity gap between the most productive firms and others has been widening the most in intangible-intensive industries (Haskel and Westlake, 2017).

What are the implications of the changing nature of innovation and the growing intangible component in goods for the competitiveness of countries? To explain these implications it is necessary to refer to M.E. Porter's concept of the competitiveness of nations. "The only meaningful concept of competitiveness at the national level is productivity. (...) A nation's standard of living depends on the capacity of its companies to achieve high levels of productivity-and to increase productivity over time" (Porter, 2008, p. 176). As productivity is at the core of the competitiveness concept intangible assets that are gaining importance in the digital age also become more and more important for competitiveness. Summing up, digitalization causes changes in the characteristics of innovation; the digital world and competitiveness is based on innovation, the nature of competitiveness is also evolving. In particular it is related to technological competitiveness grounded in technologies that make the world digital.

Therefore in this context a key question is: how to define technological (or digital) competitiveness in this new industrial revolution? There is no doubt that in the digital age productivity still remains at the centre of the competitiveness concept (Delgado, Ketels, Porter, \& Stern, 2012; Aiginger, Bärenthaler-Sieber, \& Vogel, 2013; Porter \& Heppelmann, 2014; Radman \& Belin, 2017; WEF, 2018; IMD, 2018). However some scholars observed that in the literature the broader interpretation of competitiveness is also described using terms such as "quality competitiveness" or "technological competitiveness". However these terms can be also explained narrowly with the focus on quality and/or technology (Aiginger \& Vogel, 2015, p. 499). Technological competitiveness can also be seen the context of innovative ability and adaptive capacity (Fageberg, 1996) or more broadly as the ability to produce new technical knowledge or develop 
new technologies which are economically useful (Aschhoff, Crass, Cremers, Grimpe, \& Rammer, 2010). Nevertheless the majority of studies on technological competitiveness refer to technological innovation or link it to productivity (see i.e. Fagerberg, 1996; Howells \& Michie, 1998; Narula \& Wakelin, 1998; Hemais, Barros, \& Rosa, 2005; Weresa, 2010; Zamora-Torres, 2014; Radman \& Belin, 2017). However, having explained above that the features of innovation have been changing in the digital age, it seems that the digital dimension of technological competitiveness should be distinguished and studied in depth. This term has been already used in competitiveness rankings (IMD, 2018; WEF, 2018) as well as in assessing digitalization processes in the European Union in the Digital Transformation Scoreboard (EC, 2018). However these studies focus on the digital competitiveness of countries at the macro level and digital technologies are one of its components. There are only a few attempts to analyze digital technologies separately (Ménière, Rudyk, \& Valdes, 2017).

How does digitalization impact on the competitiveness of countries? The explanation discussed in economic literature again refers to changes in productivity, which is a key element that explains competitiveness. The research on the implementation of digital technologies into production systems and the automation and connectivity in manufacturing and services proved that there is a positive impact of digitalization on productivity (Radman \& Belin, 2017; IMD, 2018; WEF, 2018; Cockburn, Henderson, \& Stern, 2018; Ungerman, Dedkova, \& Gurinova, 2018; Monaco, Bell, \& Nyamwena, 2019). Digital technology is regarded as one of the key enabling technologies (Guellec \& Paunov, 2018 , p. 18). The literature suggests that productivity gains depend on the variety of technological innovative applications, the diffusion speed and scope and strength of network effects (Aschhoff, Crass, Cremers, Grimpe, \& Rammer, 2010 , p. 29). However innovation driven by digitalization cannot be limited to technology. Technological innovations are often accompanied by marketing or organizational ones. In-house innovative activities, exchange of advanced knowledge among suppliers, producers and users of new technologies coupled with intersectoral knowledge spillovers affect the international competitiveness of countries.

Furthermore digital technologies contribute to competitiveness by opening new markets for goods and resources. Thus new demand is created and collaborative networks among producers, suppliers and users are developed (Santos, Mehrsai, Barros, Araújo, \& Ares, 2017; Ungerman, Dedkova, \& Gurinova, 2018). New demand and networking can bring cumulative positive effects that translate into economies of scope and scale. As a result additional productivity gains can occur which mean improvements of competitiveness. 


\section{Measuring technological competitiveness in the digital age}

The importance of the fourth industrial revolution in shaping the competitiveness of nations has been reflected in new methodological approaches that have been used in competitiveness rankings. Since 2017 the IMD World Competitiveness Center offers a new competitiveness index that allows the assessment of countries' ability to adopt and use digital technologies. It defines digital competitiveness breaking it down into three main factors: knowledge, technology and future readiness. Each of these factors is further divided into three elements that comprise several detailed criteria described by statistical data from international and national sources and survey data (IMD, 2017, p. 31; IMD, 2018, p. 28). The assessment of competitiveness in the digital age is based on 50 different indicators, some of them are broad and complex (i.e. GDP per capita, population) and some are narrow and focused on technological development, including digital technologies, i.e. high-tech patents as a percentage of total patent grants, wireless-broadband subscriptions).

Competitiveness in the era of the fourth industrial revolution was also assessed by the World Economic Forum in its 2018 edition of The Global Competitiveness Report. A new tool for understanding and assessing the competitiveness of countries was developed and digital components were included in the Global Competitiveness Index (GCI). The new Global Competitiveness Index 4.0 (GCI 4.0) integrates traditional competitiveness factors with new productivity drivers that will gain in importance as economies move towards the fourth industrial revolution. The idea behind this new concept is to develop a holistic approach which will allow better use of new technologies for enhancing the prosperity and wealth of nations. The new competitiveness drivers include innovation and human capital as well as 'soft' elements such as resilience and agility. The traditional and new factors are grouped into twelve pillars which are interpreted as measures of readiness for the fourth industrial revolution. These pillars form four broader categories: enabling environment, markets, human capital and the innovation ecosystem (WEF, 2018, pp. 37-38). There are 98 indicators included as the GCI 4.0 components and each of them has been re-scaled and aggregated with a certain weight. The methodology was adjusted in order to capture the factors identified by literature as important for productivity in the era of digital transformation. Over $65 \%$ of indicators used in GCI 4.0 calculations are new, however, the WEF team conducted a formal statistical test, which showed that the GCI 4.0 is highly correlated with productivity levels which confirmed that it reflects competitiveness (WEF, 2018, p. 44). It should be pointed out however that the GCI 4.0 includes countries' macroeconomic indicators, such as inflation or market capitalization (\% of GDP) as well as other general development indicators (i.e. electrification rate; pupil-to-teacher ratio in primary education). It also comprises indicators of 
ICT development (i.e. mobile-cellular telephone subscriptions; Internet users as $\%$ of adult population).

Attempts to measure directly digital competitiveness were undertaken by the European Commission. Europe 2020 strategy identified Information and Communication Technology (ICT) as one of the key drivers for smart and sustainable growth. Europe's Digital Competitiveness Report was published for the first time in 2010 in order to monitor the development of digital technologies. The focus was mainly on ICT and its impact on productivity. The model measuring this impact was based on a standard neoclassical production function where ICT-capital was taken into account as one of the inputs. Empirical estimation of this model for a panel of 19,000 European firms across thirteen countries proved that ICT impacts productivity (a coefficient was 0.023) (EC, 2010, p. 120). Further methodological developments resulted in the construction of the International Digital Economy and Society Index (EC, 2015) which measures the digital transformation of the $\mathrm{EU}$ member states. It comprises 44 indicators grouped in five dimensions: connectivity, human capital, use of Internet, integration of digital technology and digital public services (EC, 2018, p. 64). These individual indicators measure various elements of ICT advancement (i.e. percentage of households subscribing to broadband of at least 100 Mbps, SMEs' total turnover from e-commerce, people with a degree in ICT). They cover many dimensions of digitalization (technological, economic, social, psychological).

The overview of a different methodological approaches to competitiveness in the digital age presented in international competitiveness rankings allows the conclusion that the technological dimension of competitiveness and in particular, competitiveness of countries with regard to digital technologies was included as a component into the overall competitiveness assessment, but not directly measured so far. Therefore a question related to methodology is: How to measure technological competitiveness in the digital age?

Building on the literature discussed in the previous section it can be observed that technological competitiveness is strictly connected with technological innovations, which is reflected in the technological comparative advantages of a country. Technological innovations are often protected by patents which allow innovators to take advantage of their intellectual property rights and compensate for expenditure on research and development (Scotchmer, 2005; OECD, 2009). Patents are used to measure innovative activity, however, they have some merits and drawbacks as the heterogeneous, non-linear and complex nature of technological change is difficult to capture by one indicator (Archibugi \& Pianta, 1996; Popp, 2005; de Rassenfosse, Dernis, Guellec, Picci, \& van Pottelsberghe de la Potterie, 2013; Abbas, Zhang, \& Khan, 2014; Kowalski \& Michorowska, 2014; Ferraro, Dutt, \& Kerikmäe, 2017). Nevertheless patent statistics have been 
widely used for assessing the competitive position in various technology fields both at firm and country levels (for an overview of merits and drawbacks of patents and patent-based indicators and databases see: Archibugi \& Pianta, 1996; Dernis, Guellec, \& van Pottelsberghe, 2002; Archambault, 2002; Kim \& Lee, 2015; Dziallas \& Blindt, 2019). Scholars apply different techniques and indicators in patent-based analyses of technological change, such as a propensity for patenting (Pantano, Priporas, \& Stylos, 2018) modelling-based approach (Wallusch, 2015; Choi \& Song, 2018) patent citations counts (Ernst \& Omland, 2011; van Raan, 2017; Tijssen \& Winnink, 2018) or use patent-based indices: revealed technological advantages-RTA, patent h-index, patent asset index, current impact index, etc. (Marinova \& McAleer, 2003; Ernst \& Omland, 2011; Huang, Chen, Shen, Wang, \& Ye, 2015; Prud'homme, 2016; Wisla \& Sierotowicz, 2016; Montresor \& Quatraro, 2017; Makhoba \& Pouris, 2019).

This paper will draw on the strand of research that uses patent-based methodology assuming that important technological achievements are protected by patents and that they reflect technological specialization of a country. Having said in the previous section that in the era of the fourth industrial revolution digital technologies have become key enabling technologies it is assumed that innovations in digital technologies and the comparative advantage of a country in digital technologies can become a proxy for the competitiveness of digital technologies. Patent data allow a more granular view on digital technologies development in different countries.

There is a broad range of patent indicators that can be used for assessing technological competitiveness (Mehrotra, Sabitha, Nagpal, \& Mattas, 2016). Patent indicators are used to measure technological change and the specialization of countries in different technologies but they also can be considered from the economic and legal perspective (Lee, 2009). This paper focuses on the technology to which patents belong, namely digital technologies.

The technological specialization will be examined here for selected EU countries on the basis of two indicators derived from patent statistics, namely the technological specialization index and patent share index. Such an approach allows the combination of the local and global perspective with regard to the technological competitiveness of EU countries in digital technologies. The following patent-based indicators will be calculated and analyzed: (1) the Patent Share (PS) and (2) the Revealed Technological Advantage (RTA) indices. Figure 1 presents the conceptual framework of the analysis of technological competitiveness in digital technologies. It shows how local and global aspects of technological competitiveness in the field of digital technologies are captured by RTA and PS indices.

The first of these indices, i.e. the Patent Share (PS) index, is calculated to identify the specialization of individual countries in a specific field of technol- 


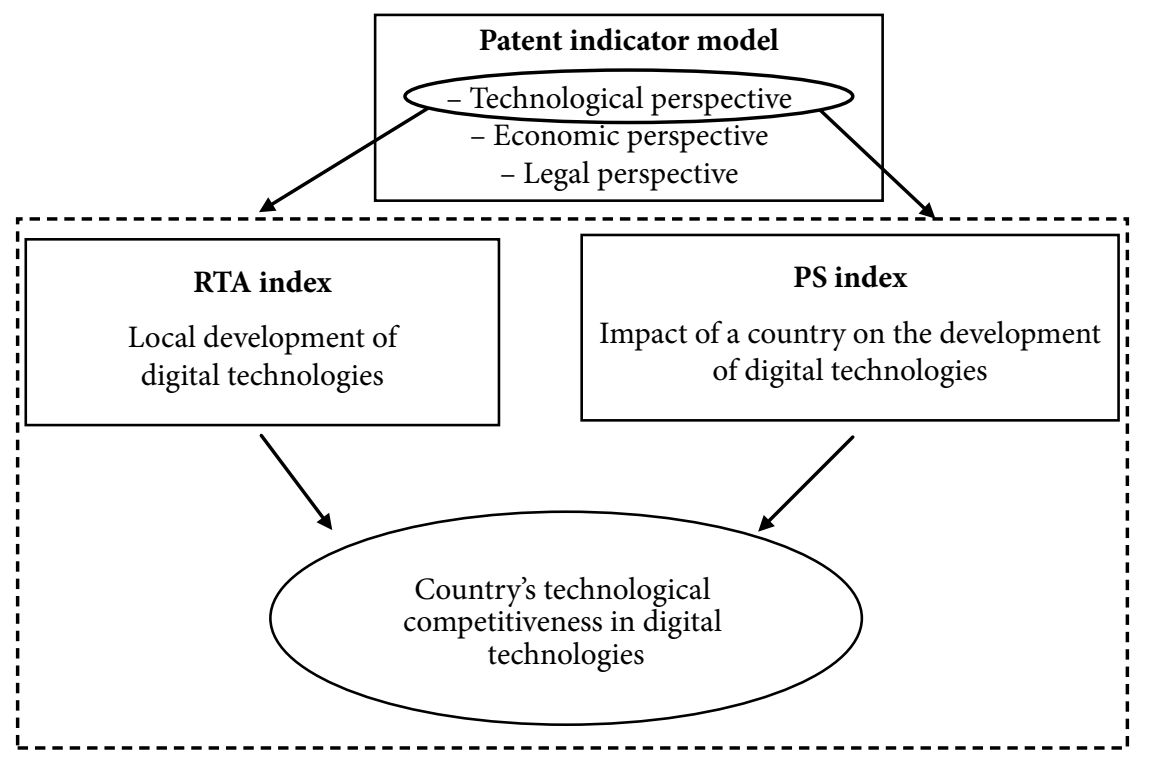

Figure 1. Competitiveness of a country in digital technologies measured by patent indicators

Source: Author's concept adapted from (Weresa, 2010).

ogy (Patel \& Pavitt, 1991). In this paper patents in technologies related to the fourth industrial revolution will be taken into account. This index is defined as follows:

$$
\mathrm{PS} i j=\frac{\mathrm{P} i j}{\sum i \mathrm{P} j}
$$

where

PSij is a share of patents in the field $j$ from country $i$ in the world patents in field $j$

P $i j=$ number of patent applications by inventor from a country $i$ in the field $j$

$\overline{\sum i \mathrm{P} j}=$ total number of world patent applications in the field $j$.

The patent share index $(0 \leq \mathrm{PS} i j \leq 1)$ reflects the impact of an individual country's patents in a particular field of technology. It can also be given as a percentage, and then it ranges between $0-100 \%$. The impact is the strongest in technologies where the highest values of the index are observed.

Another indicator, i.e. the Revealed Technological Advantage (RTA) index, measures technological advantages for selected countries (in this paper these are all EU member states) relative to other countries or the whole world (Marinova \& McAleer, 2003; Weresa, 2010; Wisla \& Sierotowicz, 2016; Montresor \& Quatraro, 2017). It reflects local development of technologies relative to other countries and is defined as follows: 


$$
\mathrm{RTA}=\frac{\mathrm{P} i j}{\sum i \mathrm{P} j}: \frac{\sum j \mathrm{P} i j}{\sum i \sum j \mathrm{P} i j}
$$

where:

P $i j=$ number of patent applications by inventor from a country $i$ in the field $j$

$\sum i \mathrm{P} j=$ total number of world patent applications in the field $j$

$\sum j \mathrm{P} i j=$ total number of patent applications by inventor of country $i$

$\sum i \sum j \mathrm{P} i j=$ total number of world patent applications.

An RTA $<1$ means that a country does not enjoy technological comparative advantages in the analyzed technology while RTA $>1$ indicates advantages in the analyzed technological field.

The data used in the empirical analysis come from the database of the European Patent Office. The European Patent Office developed criteria to extract patent applications that relate to the digital economy. These patent applications are divided into three main groups described as: core technologies, enabling technologies and application domains. The groups are further divided into several technological sub-groups (Ménière, Rudyk, \& Valdes, 2017 p. 23).

In this paper the aggregate data for all patent applications in technologies classified by the EPO as those related to the fourth industrial revolution will be taken into account. The data cover patent applications at the EPO by the inventor country in the period 2009-2016.

\section{Empirical results}

Table 1 presents the results of calculations of PS and RTA indices. The analysis is limited to the countries that have a patent share index higher than $0.1 \%$. According to the EPO data 46,895 patent applications in the technologies related to the fourth industrial revolution were submitted at the European Patent

Table 1. Digital competitiveness measured by Patent Share (PS) and Revealed Technological Advantage (RTA) indices, 2009-2016

\begin{tabular}{|l|c|c|}
\hline \multicolumn{1}{|c|}{ Countries } & Patent Share index & RTA index \\
\hline Australia & $0.4 \%$ & 0.67 \\
\hline Austria & $0.5 \%$ & 0.44 \\
\hline Belgium & $0.9 \%$ & 0.67 \\
\hline Brazil & $0.1 \%$ & 0.53 \\
\hline Canada & $3.6 \%$ & 2.70 \\
\hline Switzerland & $1.4 \%$ & 0.30 \\
\hline
\end{tabular}




\begin{tabular}{|c|c|c|}
\hline China, People's Republic of & $5.6 \%$ & 2.12 \\
\hline Czech Republic & $0.1 \%$ & 0.67 \\
\hline Germany & $8.3 \%$ & 0.48 \\
\hline Denmark & $0.7 \%$ & 0.58 \\
\hline Estonia & $0.1 \%$ & 2.83 \\
\hline Spain & $0.9 \%$ & 0.92 \\
\hline Finland & $1.7 \%$ & 1.45 \\
\hline France & $5.6 \%$ & 0.84 \\
\hline United Kingdom & $3.3 \%$ & 0.99 \\
\hline Greece & $0.1 \%$ & 1.25 \\
\hline Hungary & $0.1 \%$ & 1.59 \\
\hline Ireland & $0.4 \%$ & 0.92 \\
\hline Israel & $1.0 \%$ & 1.33 \\
\hline India & $1.1 \%$ & 3.01 \\
\hline Italy & $1.0 \%$ & 0.39 \\
\hline Japan & $18.7 \%$ & 1.31 \\
\hline Korea, Republic of & $11.4 \%$ & 3.02 \\
\hline Luxembourg & $0.1 \%$ & 0.20 \\
\hline Netherlands & $1.7 \%$ & 0.40 \\
\hline Norway & $0.2 \%$ & 0.52 \\
\hline Poland & $0.3 \%$ & 1.16 \\
\hline Portugal & $0.1 \%$ & 1.08 \\
\hline Romania & $0.1 \%$ & 4.46 \\
\hline Russian Federation & $0.3 \%$ & 2.53 \\
\hline Saudi Arabia & $0.1 \%$ & 0.47 \\
\hline Sweden & $2.3 \%$ & 0.94 \\
\hline Turkey & $0.1 \%$ & 0.37 \\
\hline Chinese Taipei & $1.3 \%$ & 1.62 \\
\hline United States & $26.8 \%$ & 1.08 \\
\hline South Africa & $0.1 \%$ & 0.76 \\
\hline UE-28 & $28.2 \%$ & 0.64 \\
\hline TOTAL & $100.0 \%$ & 1.00 \\
\hline
\end{tabular}

Source: Own elaboration based on European Patent Office data. 
Office by 88 countries in the in the period of $1990-2016.61 \%$ of these patent applications were submitted during the period analyzed in this paper, i.e. the years 2009-2016.

A first step in this analysis is to define technological competitiveness in digital technologies of the EU as a whole. The share of digital patent applications submitted by the EU countries (EU-28) was relatively stable and in the years 2009-2016 it amounted to $28 \%$. The impact of the EU on digital technologies' development when measured by patent share index is slightly higher than that of the US. In 2009-2016 the latter had the share of $26.8 \%$ in the world patent applications in digital technologies. Japan is the third most impactful country in this respect (18.7\%), followed by the South Korea (11.4\%) and China (5.6\%). Looking separately at each EU member state the strong position of Germany should be pointed out. This country's patent share index for the period of 2009-2016 amounted to 8.3\%. Other EU countries that have a relatively high share in world patent applications in digital technologies are: France, the UK and Sweden (with shares standing at 5.6\%, 3.3\% and 2.3\% respectively) (see Table 1 and Figure 2).



Korea; $11.4 \%$

Figure 2. The impact of the EU patents on the world's patent portfolio in the field of digital technologies as reflected by the Patent Share index in 2009-2016 Source: Own elaboration based on European Patent Office data.

However despite the relatively high PS index in the field of technologies related to the fourth industrial revolution for the $\mathrm{EU}$ as a whole and for some EU member states, technological competitiveness of the EU measured by the RTA index is quite weak. Digital technologies do not belong to the EU technological specialization as the RTA index in 2009-2016 was below one, amounting only to 0.64 . Other countries with high patent shares such as the USA, Japan, the South Korea and China enjoyed technological comparative advantages in digital technologies (their RTA indices were respectively: 1.08; 1.31; 3.02 and 
South Korea

India

Canada

Russian Federation

China

Israel

Japan

United States

UE-28

Brazil

0.00

0.50

1.00

2.00

2.50

3.00

3.50

Figure 3. Specialization in digital technologies as measured by the RTA index:

EU compared to selected countries, 2009-2016

Note: RTA > 1 indicates relative specialization in a given technological field.

Source: Own elaboration based on European Patent Office data.

2.12, see Table 1 and Figure 3). Figure 3 clearly shows that the EU as a whole did not specialize in digital technologies in the period of 2009-2016, while majority of its peers did.

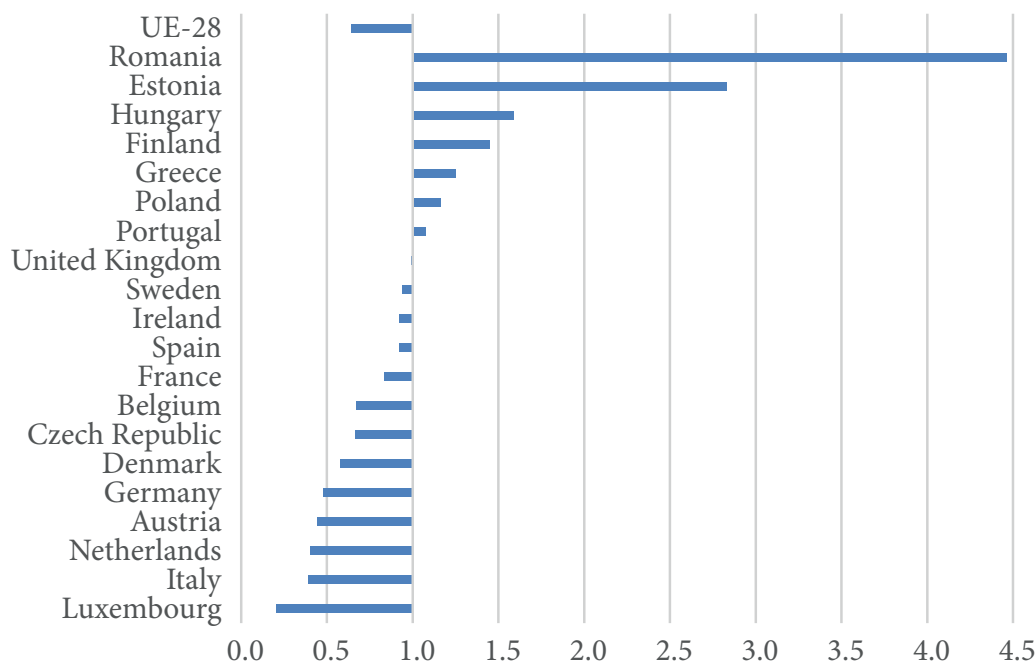

Figure 4. Specialization in digital technologies of the EU member states as measured by the RTA index, 2009-2016

Note: A relative patent advantage index $>1$ indicates relative specialization in a given technological field. The figure shows data on the RTA index for those EU members states that have some impact on digital technologies' development, i.e. their patent share index higher than $0.1 \%$.

Source: Own elaboration based on European Patent Office data. 
The results however vary for individual EU member states. Only seven EU countries enjoy technological comparative advantages in digital technologies. These are: Estonia, Finland, Greece, Hungary, Poland, Portugal and Romania. Paradoxically, apart from Finland, these countries do not belong to the most impactful EU member states in digital technologies as their patent shares are very low, below $0.5 \%$. Finland is the only exception in this group with the PS index equal to $1.7 \%$ (Table 1 and Figure 4).

It should also be pointed out that four out of seven EU members that enjoy technological advantages are countries from Central and Eastern Europe that joined the EU in the first decade of the 21st century. It is a new feature of their patenting activity. With low patent counts they are still relatively more focused on protecting their intellectual property in digital technologies than in other technological fields.

However when interpreting empirical results, in particular values of RTA indices, it should be remembered that data cover only patent applications in digital technologies classified by country of inventor and submitted to the European Patent Office. The data from other patent offices and classified using another perspective (i.e. classified by country of the applicant) may bring deviations in the patterns observed as companies may differentiate their innovative strategies adjusting them to particular markets and, as a consequence, behave differently with regard to intellectual property protection. Data from other sources (patent applications under PCT procedures, patents granted from the US Patent Office, etc.) have not been taken into account due to the unavailability of such detailed patent statistics for digital technologies.

There is however a possibility to compare the results of this empirical analysis with findings presented by the OECD for the whole range of ICT technologies. ICT technologies are a much broader category but they also comprise some digital technologies but not all of them. ${ }^{3}$ However it is commonly acknowledged that the development of ICT technologies to some extent represents the level of a country's digitalization (OECD, 2017; WEF, 2018; IMD, 2018; EC, 2018). Therefore the OECD data on patent applications in the ICT technologies and

${ }^{3}$ In the OECD statistics the ICT sector covers ISIC Rev.4 Divisions 26, 61 and 62-63 (Computer and electronics, Telecommunications, and IT and other information services) (OECD, 2017, p. 176). This classification differs from the one distinguished in the publication of the European Patent Office. Data on patent applications related to the fourth industrial revolution provided by the EPO are classified into three main sectors and further subdivided into several technology fields (Ménière, Rudyk, \& Valdes, 2017, p. 23). These are: core technologies (hardware, software and connectivity) that enable transformation of objects into smart connected devices, enabling technologies (analytics, security, artificial intelligence, position determination, power supply, 3D systems, user interfaces) and application domains (home, personal, enterprise, manufacturing, infrastructure, vehicles) where the potential of connected objects can be exploited (for detailed classification by CPC codes see: Ménière, Rudyk, \& Valdes, 2017, pp. 87-93). 


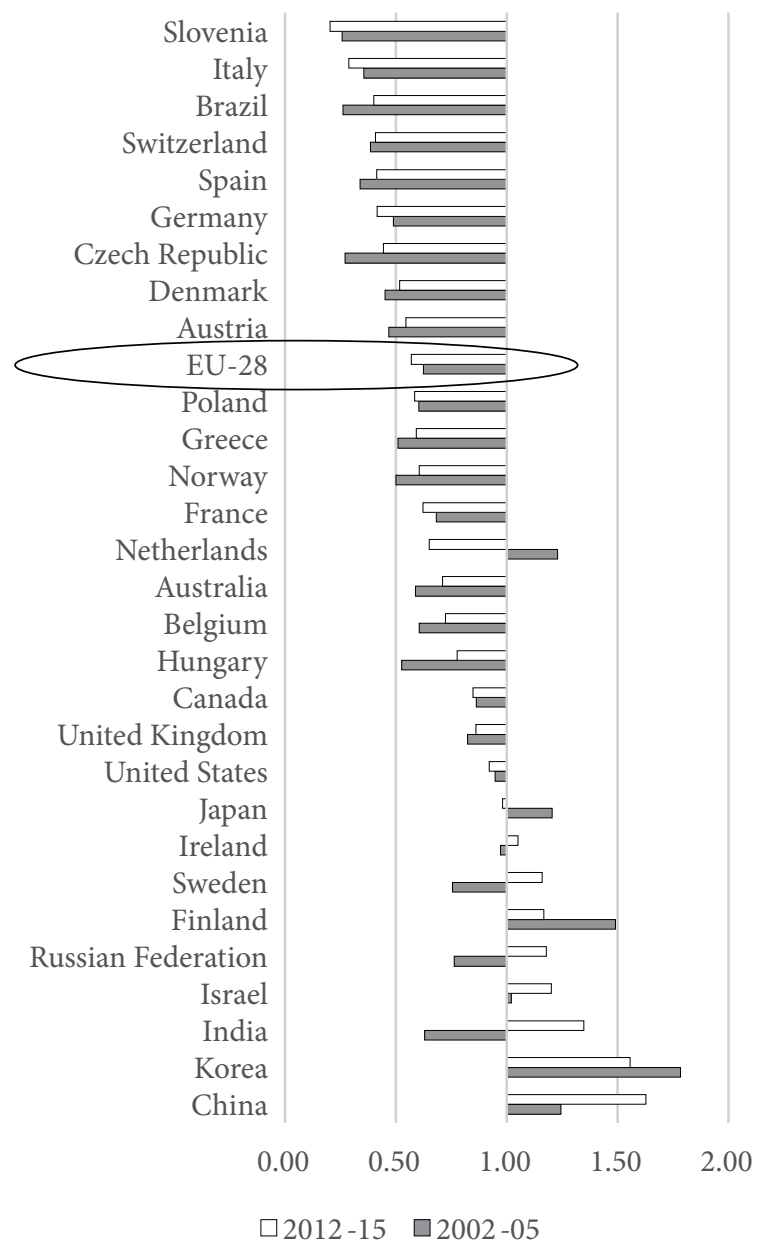

Figure 5. Specialization in ICT technologies as measured by RTA index, 2002-2015

Note: A relative patent advantage index $>1$ indicates relative specialization in a given technological field. The index is calculated on the basis of patent families within the Five IP Offices (IP5), by inventor country.

Source: Own elaboration based on data derived from OECD, STI Micro-data Lab: Intellectual Property Database, http://dx.doi.org/10.1787/888933619752, accessed on August 6, 2019.

calculations of the RTA index can also be used as a proxy for the technological competitiveness in the field of digital technologies.

According to the OECD there have been changes in relative technological specialization in ICT over the 2002-2015 period. In particular China and India increased their relative specialization in ICT as measured by the RTA index, while Korea and Finland decreased their specialization (OECD, 2017, p. 178). The EU as a whole increased its specialization in ICT technologies but despite 
this, it does not enjoy comparative advantages in this technology group. Figure 5 shows a detailed picture of relative specialization in ICT technologies and their changes over the 2002-2015 period measured by the RTA index. The index is calculated by the OECD on the basis of patent families within the Five Intellectual Property Offices (IP5). Patents are classified by inventor country.

It is worth comparing the OECD findings on countries' relative technological advantages in ICT technologies with the results of the analysis conducted in this paper for narrowly defined digital technologies. However before conducting such comparative analysis some important remarks should be given. One should note that there are differences in the data used in both analysis, such as the period of analysis, definition of technologies, patent offices where the applications have been filed. Therefore a comparison of the results of both analyses is limited to some tentative observations about similarities and differences in patterns of technological specialization.

It appears that the EU as a whole does not reveal a relative specialization in digital and ICT technology groups as opposed to its emerging global competitors, such as Korea, China, India, and the Russian Federation, which enjoyed relative advantages in both groups of technologies (see Figures 3 and 5). The case of the US is different as this country enjoys some small comparative technological advantage in digital technologies $(\mathrm{RTA}=1.08)$, while it did not have comparative advantages in the ICT technologies and its position in this field even decreased in 2012-2015 (see Figures 3 and 5).

When it comes to individual EU member states only one EU country, namely, Finland, enjoys comparative technological advantages in ICT and digital technologies. ICT also belongs to the relative technological specialization in Sweden and Ireland. Other EU countries for which the digital technologies were relatively advantageous (i.e. their patenting activity in this technological field, although small, was more intensive than the average in the world) did not enjoy technological advantages in ICT technologies (see Figures 4 and 5).

All in all the findings of the OECD about the technological advantages of various countries in ICT technologies indicate that tendencies in technological competitiveness (specialization) of countries in ICT are quite similar to the ones revealed in the analysis of technological competitiveness in digital technologies conducted in this paper. These tentative conclusions should be treated with caution keeping in mind the limitations related to comparability of the data discussed.

\section{Conclusions}

Summing up the results of the empirical analysis indicate that, on the one hand, the EU as a whole has a quite high impact on the world patenting in the field of digital technologies confirmed by the high Patent Share index (PS $=28.2 \%)$, but 
on the other hand, it does not have comparative advantages in these technologies (RTA index $=0.64$, i.e. below 1$)$. However looking at the individual member states it can be observed that the EU can be divided into three sub-groups in terms of digital competitiveness measured by patenting activity in technologies related to the fourth industrial revolution. A few EU member states are amongst the world leaders in terms of the Patent Share index but they do not enjoy comparative advantages in these technologies compared to the whole world. These are: Germany, France, the UK and Sweden. Another group of EU member states consists of seven countries, such as Estonia, Finland, Hungary, Poland, Romania, Portugal and Greece. They are not strong in terms of the number of patent applications in digital technologies as they have a very low patent share in the world in this technological field. However they enjoy a comparative technological advantage $(\mathrm{RTA}>1)$ in digital technologies. The rest of the EU countries form the third group that is neither impactful, nor advantageous in technologies related to the fourth industrial revolution.

When one compares these findings with the OECD data on revealed comparative advantages in the whole group of ICT technologies, it appears that for the EU as a whole, as well as for the first and the third group of EU coun-

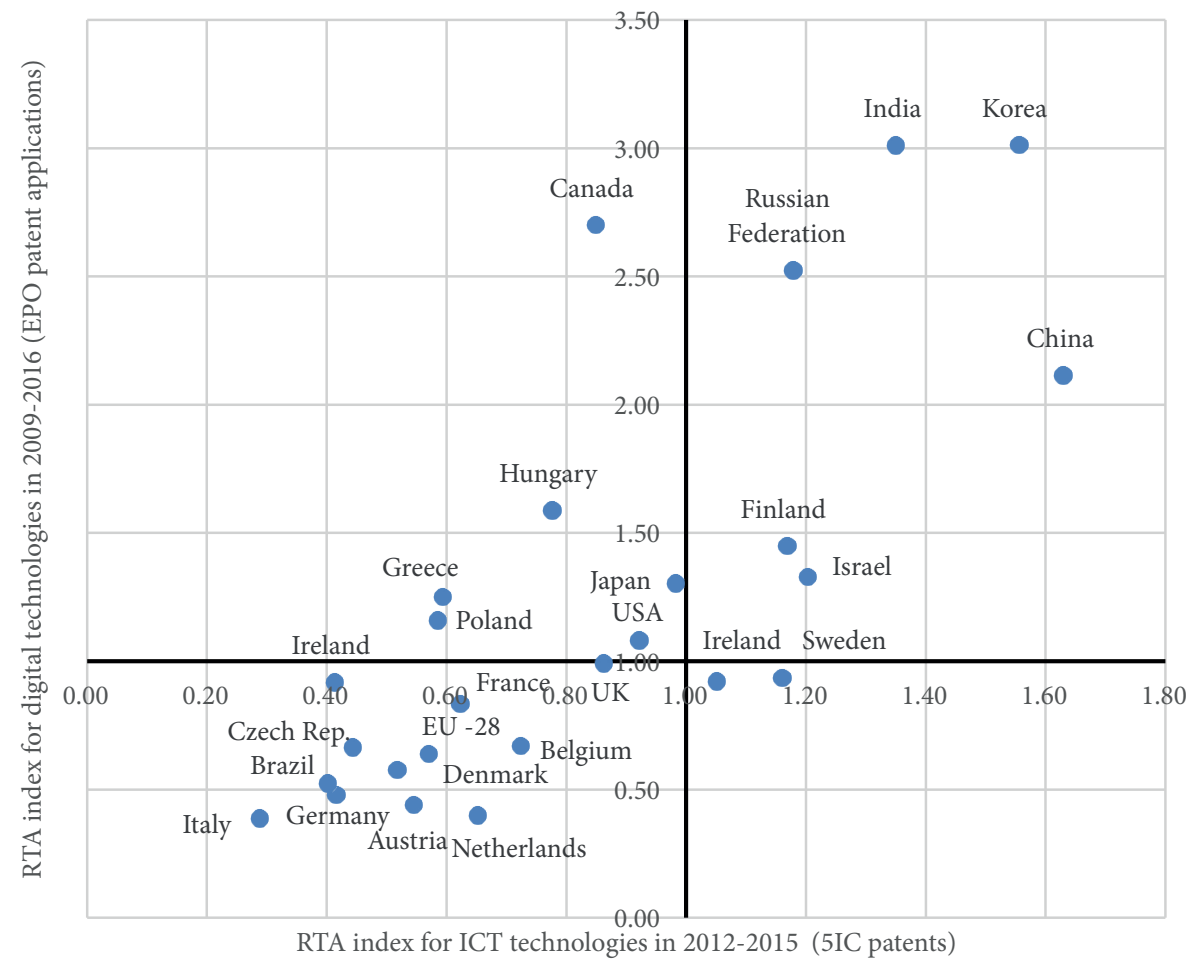

Figure 6. The RTA indices in ICT in 2012-2015 and the RTA indices in digital technologies in 2009-2016

Source: Own elaboration based on the OECD database and European Patent Office data. 
tries distinguished above, the technological competitiveness pattern is similar in both technological fields (i.e. ICT and digital technologies). In the second group classified as not impactful, but relatively advantageous, in the field of digital technologies a similar pattern for ICT and digital technologies was observed only in Finland. This country enjoys comparative advantage in broadly understood ICT technologies as well as in narrowly defined digital technologies that are related to the fourth industrial revolution. In other countries that belong to this group specialization patterns differ for ICT and digital technologies. Figure 6 plots these two variables (RTA in ICT and RTA in digital technologies) in order to illustrate the tendencies observed.

The results of this research should be interpreted with caution keeping in mind the narrow definition of competitiveness in digital technologies as well as several limitations of the methodology used in the analysis. Although patent statistics and in particular, the PS and RTA indices based on patents are useful proxies to gauge technological competitiveness these empirical research tools face several limitations. There are some limitations related to the usage of patent statistics as a proxy for innovation and technological competitiveness as broadly discussed in the literature. In the context of digital competitiveness the main weakness of patents as indicators is that they represent only one dimension of technological development. A multidimensional approach that also includes other elements, such as human resources that are necessary for the development of digital technologies, may throw some additional light on this topic. There are also some other limitations related to the indices used in this paper. They adequately capture relative revealed technological advantages, however they do not take into account commercialization of these of new inventions. Thus the use of rudimentary indicators allows a comparison of countries in terms of the relative number of patents but the patent value has not been included in this analysis. Furthermore patent activity in digital technologies increases more quickly than in any other field of technology. As this technology field represents a technology with the broadest interdisciplinary profile a typology of these patents worked out by the European Patent office changes over time, which makes it difficult to aggregate and compare results achieved in different periods. Last but not least, this analysis is limited to the EPO database. The European Patent Office is one of the key patent offices in the world, however, it may be useful replicate these empirical research using data from other patent databases (US Patent Office, Japanese Patent Office, etc.) and compare the results. At this stage it is not possible to extend research in this direction because so far only the EPO has attempted to prepare a patent map for technologies used in the fourth industrial revolution. With the growing role of information and communication technologies and the rapid expansion of digitalization it seems that further extensive research is needed to bring some new empirical evidence which explains this new dimension of competitiveness. 


\section{References}

Abbas A., Zhang, L., \& Khan, S. U. (2014). A literature review on the state-of-the-art in patent analysis. World Patent Information, 37, 3-13.

Aiginger, C., \& Vogel, J. (2015). Competitiveness: From a misleading concept to a strategy supporting Beyond GDP goals. Competitiveness Review, 25(5), 497-523.

Aiginger, K., Bärenthaler-Sieber, S., \& Vogel, J. (2013, October). Competitiveness under new perspectives. (WWW for Europe Working Paper No. 44). Vienna: WIFO.

Archambault, É. (2002). Methods for using patents in cross-country comparisons. Scientometrics, 54(1), 15-30.

Archibugi, D., \& Pianta, M. (1996). Measuring technological change through patents and innovation surveys. Technovation, 16(9), 451-468.

Aschhoff, B., Crass, D., Cremers, K., Grimpe, Ch., \& Rammer, Ch. (2010). European competitiveness in key enabling technologies. Centre for European Economic Research (ZEW). Retrieved from https://nanonet.pl/wp-content/uploads/2018/02/ European-Competitiveness-in-Key-Enabling-Technologies.pdf

BMBF. (2013). Zukunftsbild Industrie 4.0. Berlin: Bundesministerium für Bildung und Forschung.

Chiappini, R. (2014). Persistence vs. mobility in industrial and technological specialisations: evidence from 11 Euro area countries. Journal of Evolutionary Economics, 24(1), 159-187.

Choi, D., \& Song, B. (2018). Exploring technological trends in logistics: Topic modeling-based patent analysis. Sustainability, 10(8), 1-26.

Cockburn, I., Henderson R., \& Stern S. (2018). The impact of artificial intelligence on innovation. (NBER Working Paper, No. 24449). National Bureau of Economic Research. Retrieved from http://dx.doi.org/10.3386/w24449

Delgado, M., Ketels, Ch., Porter, M. E., \& Stern, S. (2012). The determinants of national competitiveness. (NBER Working Paper No. 18249).

Dernis, H., Guellec, D. \& van Pottelsberghe, B. (2002). Using patent counts for crosscountry comparisons of technology output. STI Review, 27, 129-146. Special Issue on New Science and Technology.

Dziallas, M., \& Blindt, K. (2019). Innovation indicators throughout the innovation process: An extensive literature analysis. Technovation, 80-81, 3-29.

EC. (2010). Europe's digital competitiveness report 2010. Luxembourg: Publications Office of the European Union.

EC. (2015). Monitoring the digital economy \& society 2016-2021. Brussels: European Commission, DG Communications Networks, Content \& Technology.

EC. (2018). Digital transformation scoreboard 2018. EU businesses go digital: Opportunities, outcomes and uptake internal market. Luxembourg: Publications Office of the European Union.

Ernst, H., \& Omland, N. (2011). The Patent Asset Index: A new approach to benchmark patent portfolios. World Patent Information, 33, 34-41

Fagerberg, J. (1996, September). Technology and competitiveness. Oxford Review of Economic Policy, 12(3), 39-51. Retrieved from https://doi.org/10.1093/oxrep/12.3.39

Ferraro, S., Dutt, P. K., \& Kerikmäe, T. (2017). Using patent development, education policy and research and development expenditure policy to increase technological 
competitiveness of small European Union member states. Croatian International Relations Review, 23(78), 97-126.

Grossman, G. E., \& Helpman, E. (1989). Comparative advantage and long-run growth. (NBER Working Papers 2809). National Bureau of Economic Research, Inc.

Guellec, D., \& Paunov, C. (2018). Innovation policy in the digital age. OECD Science, Technology and Innovation Policy Papers, 59.

Haskel, J., \& Westlake S. (2017). Capitalism without capital: The rise of the intangible economy. Princeton: Princeton University Press.

Hemais, C. A., Barros, H. M., \& Rosa, E. O. R. (2005, July). Technology competitiveness in emerging markets: The case of the Brazilian polymer industry. Journal of Technology Transfer, 30(3), 303-314.

Howells, J., \& Michie, J. (1998). Technological competitiveness in an international arena. International Journal of the Economics of Business, 5(3), 279-293.

Huang, M.-H., Chen, D.-Z., Shen, D., Wang, M. S., \& Ye, F. Y. (2015). Measuring technological performance of assignees using trace metrics in three fields. Scientometrics, 104, 61-86.

IMD. (2017). IMD World Digital Competitiveness Ranking 2017. Lausanne: The IMD World Competitiveness Center. Retrieved from www.imd.org/wcc

IMD (2018). IMD World Digital Competitiveness Ranking 2018. Lausanne: The IMD World Competitiveness Center. Retrieved from www.imd.org/wcc

Kagermann, H., Helbig, J., Hellinger, A., \& Wahlster, W. (2013). Recommendations for implementing the strategic initiative INDUSTRIE 4.0: Securing the future of German manufacturing industry. Final report of the Industrie 4.0 working group, Forschungsunion.

Kim, J., \& Lee, S. (2015). Patent databases for innovation studies: A comparative analysis of USPTO, EPO, JPO and KIPO. Technological Forecasting and Social Change, 92(C), 332-345

Kowalski, A. M., Michorowska, B. (2014). Methods for measuring innovation. In M. A. Weresa (Ed.), Innovation, human capital and trade competitiveness. how are they connected and why do they matter? (pp. 74-78). Heidelberg, New York, London: Springer.

Lee, Y.-G. (2009). What affects a patent's value? An analysis of variables that affect technological, direct economic, and indirect economic value: An exploratory conceptual approach. Scientometrics, 79(3), 623-633.

Makhoba, X., \& Pouris, A. (2019). A patentometric assessment of selected R\&D priority areas in South Africa: A comparison with other BRICS countries. World Patent Information, 56, 20-28.

Marinova, D., \& McAleer, M. (2003). Nanotechnology strength indicators: International rankings based on US Patents. Nanotechnology, 14(1), R1-R7(7).

Mehrotra, D., Sabitha, S., Nagpal, R., \& Mattas, N. (2016). Landscape analysis of patent dataset. Journal of Intellectual Property Rights, 21, 211-225.

Ménière, Y., Rudyk, I., \& Valdes, J. (2017). Patents and the fourth industrial revolution. The inventions behind digital transformation. Munich: European Patent Office.

Monaco, L., Bell, J. \& Nyamwena, J. (2019, February 28). Understanding technological competitiveness and supply chain deepening in plastic auto components in Thailand: Possible lessons for South Africa. (CCRED Working Paper No. 1/2019). Retrieved 
from https://ssrn.com/abstract=3384027 or http://dx.doi.org/10.2139/ssrn. 3384027

Montresor, S., \& Quatraro, F. (2017). Regional branching and key enabling technologies: Evidence from European patent data. Economic Geography, 93(4), 367-396. doi: $10.1080 / 00130095.2017 .1326810$

Morrar, R., Arman, H., \& Mousa, S. (2017). The fourth industrial revolution (Industry 4.0): A social innovation perspective. Technology Innovation Management Review. Retrieved from file://C:/Documents\%20and\%20Settings/bkam/Pulpit/Morrar_et_ al_TIMReview_November2017.pdf,17.02.2019.

Narula, R., \& Wakelin, K. (1998, September). Technological competitiveness, trade and foreign direct investment. Structural Change and Economic Dynamics, 9(3), 373-387.

OECD. (2009). Patent Statistics Manual. Paris: OECD Publishing.

OECD. (2017). OECD Science, Technology and Industry Scoreboard 2017: The digital transformation. Paris: OECD Publishing. Retrieved from http://dx.doi. org/10.1787/9789264268821-en

OECD. (2019). Digital innovation: Seizing policy opportunities. Paris: OECD Publishing. Retrieved from https://doi.org/10.1787/a298dc87-en

Pantano, E., Priporas, K.-V., \& Stylos, N. (2018). Knowledge Push Curve (KPC) in retailing: Evidence from patented innovations analysis affecting retailers' competitiveness. Journal of Retailing and Consumer Services, 44, 150-160.

Patel, P., \& Pavitt, K. (1991). Europe's technological performance. In C. Freeman, M. Sharp, \& W. Walker (Eds.), Technology and the future of Europe (pp. 35-58). London: Pinter.

Planes-Satorra, S., \& Paunov, C. (2019, May). The digital innovation policy landscape in 2019. OECD Science and Innovation Policy Papers, 71.

Popp, D. (2005). Lessons from patents: Using patents to measure technological change in environmental models. Ecological Economics, 54(2-3), 209-226.

Porter, M. E. (2008). On Competition. Boston: Harvard Business School Publishing.

Porter, M. E., \& Heppelmann, J. E. (2014, November). How smart, connected products are transforming competition. Harvard Business Review, 92(11), 64-88.

Prud'homme, D. (2016). Dynamics of China's provincial-level specialization in strategic emerging industries. Research Policy, 45(8), 1586-1603

Radman, G., \& Belin, A. (2017). Competitiveness in technology and innovation: How to keep on?. International Journal of Digital Technology \& Economy, 2(1), 45-56.

Rassenfosse, G. de, Dernis, H., Guellec, D., Picci, L., \& van Pottelsberghe de la Potterie, B. (2013). The worldwide count of priority patents: A new indicator of inventive activity. Research Policy, 42(3), 720-737.

Santos, C., Mehrsai, A., Barros, A. C. Araújo, M., \& Ares, E. (2017). Towards Industry 4.0.: An overview of European strategic roadmaps. Procedia Manufacturing, 13, 972-979.

Schwab, K. (2016). The fourth industrial revolution. Geneva: World Economic Forum. Scotchmer, S. (2005). Innovation and incentives. Cambridge: MIT Press.

Tijssen, R. \& Winnink, J. (2018). Capturing 'R\&D excellence': Indicators, international statistics, and innovative universities. Scientometrics, 114(2), 687-699.

Uchida, Y., \& Cook, P. (2005). The effects of competition on technological and trade competitiveness. Quarterly Review of Economics and Finance, 45(2-3), 258-283. 
Ungerman, O., Dedkova, J. \& Gurinova, K. (2018). The impact of marketing innovation on the competitiveness of enterprises in the context of Industry 4.0. Journal of Competitiveness, 10(2), 132-148.

van Ark, B., Hao, J. X., Corrado, C., \& Hulten, Ch. (2009). Measuring intangible capital and its contribution to economic growth in Europe. European Investment Bank, 14(1), 62-93.

van Raan, A. F. J. (2017). Patent citations analysis and its value in research evaluation: A review and a new approach to map technology-relevant research. Journal of Data and Information Science, 2(1), 13-50.

Wallusch, J. (2015). (Un)finished transition. Stock of knowledge in Poland, 1924-2012. Economics and Business Review, 15(1), 89-102. doi: 10.18559/ebr.2015.1.7

WEF. (2018). The Global Competitiveness Report 2018. Geneva: World Economic Forum.

Weresa, M. A. (2010). Intellectual property rights and competitiveness: evidence from Poland. International Journal of Foresight and Innovation Policy, 6(4), 233-247.

Weresa, M. A. (2019). Stan i bariery rozwoju Przemysłu 4.0 w Polsce. In A. M. Kowalski, M. A. Weresa (Eds.), Konkurencyjność międzynarodowa Polski w kontekście czwartej rewolucji przemysłowej i Przemysłu 4.0. Warszawa: Oficyna Wydawnicza SGH (forthcoming).

Wisla, R., \& Sierotowicz, T. (2016). Medical technological specializations of central and eastern European regions. Economics and Sociology, 9(3), 195-209. doi: 10.14254/2071-789X.2016/9-3/17

Zamora-Torres, A. (2014). Countries competitiveness on innovation and technology. Global Journal of Business Research, 8(5), 73-83. 